\title{
COVID-19 Pandemic and Simultaneous Regional Head Elections in Indonesia
}

\author{
Aniqotun Nafiah* \\ University of Mubammadiyah Surabaya, Indonesia
}

\author{
Nur Azizah Hidayat \\ University of Muhammadiyah Surabaya, Indonesia
}

\begin{abstract}
The COVID-19 pandemic hurts almost all sectors, particularly the government, like the simultaneous Regional Head Election. The Indonesian government, along with the General Election Commission and the Indonesian House of Representatives through the Government Regulation in Lieu of Law No. 2 of 2020, agreed to postpone it until December 2020 to reduce the spread of COVID-19. To date, the pandemic has not ended yet, considered that the delay might be ineffective. Another issue was the emergence of other simultaneous elections in 2024, in which several steps have begun to be implemented this year. This study aimed to discuss the issue of the simultaneous regional head elections during the pandemic. It raised two issues. First, while the elections were still held to avoid vacancies, their implementation must be adjusted to the COVID-19 pandemic. Second, while the elections were postponed until the pandemic ends, the Acting Officer, as another alternative, should be given full authority to the Acting Officer so that the government could be administered optimally. The study combined doctrinal and empirical legal research. The primary data sources were the laws and regulations relating to the Regional Head Elections in Indonesia and interviews from the Election Supervisory Committee in Surabaya, Indonesia. This study showed that the simultaneous elections during the COVID-19 pandemic could still avoid vacancies, and its implementation was adjusted to the pandemic situation. Therefore, it implemented strict health protocols despite the more detailed and comprehensive-time simulations to adjust the overall implementation of the upcoming election stages. Also, the internet infrastructure was prevalent to support the elections. Finally, the government established the guidelines for Regional Head Election based on the COVID-19 health protocol.
\end{abstract}

KEYWORDS: COVID-19 Pandemic, Regional Head Election, Regional Head Authority.

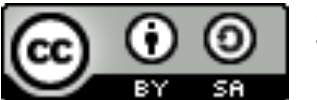

Copyright $\odot 2021$ by Author(s)

This work is licensed under a Creative Commons Attribution-ShareAlike 4.0 International License. All writings published in this journal are personal views of the authors and do not represent the views of this journal and the author's affiliated institutions.

HOW TO CITE:

Nafiah, Aniqotun \& Nur Azizah Hidayat, "COVID-19 Pandemic and Simultaneous Regional Head Elections in Indonesia" (2021) 2:2 Indonesian Journal of Law and Society 145-164, online: <https://doi.org/10.19184/ijls.v2i2.24661>.

Submitted: 10/06/2021 Reviewed: 29/08/2021 Revised: 18/09/2021 Accepted: 19/09/2021

\footnotetext{
* Corresponding authors' e-mail: aniqatun777@gmail.com
} 


\section{INTRODUCTION}

Coronavirus Disease 2019 (COVID-19) was first found in Wuhan, China, in 2019. ${ }^{\circ}$ Over time, the virus began to attack almost all countries in early 2020, including Indonesia. The World Health Organization (WHO) announced on March 11, 2020, that this virus had been a pandemic. ${ }^{2}$ Until May 27, 2021, there were 1,791,221 confirmed cases in Indonesia and $167,951,168$ confirmed cases across the globe. ${ }^{3}$ The rapid transmission of COVID-19 endangers human health, which causes death. ${ }^{4}$ Therefore, several countries implemented lockdown, and to a certain extent, the Large-Scale Social Restrictions as Indonesia did. The Large-Scale Social Restrictions were directed in Government Regulation 21/2020 that handled the COVID-19 outbreak. ${ }^{5}$ In practice, Large-Scale Social Restrictions limited almost all social activities, including the closure of worship places, schools, and universities. It also restricted several activities that were feared to cause crowds that resulted in the COVID-19 transmission. This restriction was the government's effort to suppress the COVID-19 transmission. Consequently, it also harms all sectors. Some of the sectors affected were the economy, education, tourism, sports, and government. In the government sector, the most public's concern had Regional Head Election amid the COVID-19 pandemic. ${ }^{6}$

1 Bao-Liang Zhong, et al., "Knowledge, attitudes, and practices towards COVID-19 among Chinese residents during the rapid rise period of the COVID-19 outbreak: a quick online cross-sectional survey" (2020) 16:10 Int J Biol Sci 1745-1752 at 16.

2 Domenico Cucinotta \& Maurizio Vanelli, "WHO Declares COVID-19 a Pandemic" (2020) 91:1 Acta Bio-Medica Atenei Parm 157-160.

3 WHO, "WHO Coronavirus (COVID-19) Dashboard | WHO Coronavirus (COVID-19) Dashboard With Vaccination Data", online: <https://covid19.who. int/>.

4 José Ricardo Navarrro-Vargas, "The COVID-19 pandemic" (2020) 68:1 Rev Fac Med 7-8 at 68.

5 Dian Herdiana, "Implementasi Kebijakan Pembatasan Sosial Berskala Besar (Psbb) Sebagai Upaya Penanggulangan Corona Virus Disease 2019 (COVID-19)" (2020) 2:2 Decis J Adm Publik 14.

6 Nila Nargis \& M Iwan Satriawan, "Legal Problems on Regional Head Election during COVID-19 Pandemic in Indonesia" (2021) 2:1 Constitutionale 69-78. 
The government rescheduled the Regional Head Election through Government Regulation in Lieu of Law 2/2020 until December 2020. This rescheduling was not realistic since the cases of COVID-19 transmission in Indonesia were increasing. This ineffectiveness emerged, so the election must also be postponed since the primary foundation stages have been postponed. It is necessary to be understood if it is impossible to hold elections according to the agenda contained in the law if the pandemic has not been entirely over. ${ }^{8}$ In this case, the government should first focus on handling the pandemic and equally strive for the people's welfare. However, the government inferred that Regional Head Election could not be delayed in a long time because of the possible void position for regional heads in several regions. At the same time, the pandemic could not be ascertained when it would end. ${ }^{9}$ The vacancy of the position of the regional head during the pandemic has raised concerns as the regional governments need the upcoming leader to handle a crisis during a pandemic. It is one of the reasons why the Regional Head Election must still be held even though the virus spread in Indonesia is increasing.

This study aimed to discuss the issue of the simultaneous regional head elections during the pandemic. It enquires to what extent the election's stages could remain held without crowds to anticipate the spread of COVID-19. Consequently, there is no void position for regional heads. First, replacing the conventional election stages using technology developed in industrial society 4.0 based on the Internet of Things (IoT) temporarily (pandemic urgency) or with alternatives adapted to the pandemic situation. Secondly, while the election is postponed until the pandemic ends, the Acting Officers as another alternative to replace the position of the regional head with the provision that the Acting Officers is given full authority to administer the government optimally. It aims to avoid the overlapping

7 Putri Hergianasari, "Electoral Distancing: Alternatif Penyelenggaraan Pemilihan Kepala Daerah 2020 Ditengah Covid-19 Di Indonesia” (2020) 1:1 Magistrorum Sch J Pengabdi Masy 112-121.

8 David Greacy Geovanie, "Urgensi Penyelenggaraan Pilkada Pada Masa Pandemi Covid-19 di Indonesia” (2020) 1 J Locus Delicti 7.

9 Aprista Ristyawati, "Efektivitas Pelaksanaan Pilkada Serentak 2020 Pada Masa Pandemi Darurat Covid-19 Di Indonesia” (2020) 2:2 CREPIDO 85-96. 
regulations of Government Regulation 21/2020 and the Government Regulation in Lieu of Law 2/2020.

According to Nandang Alamsab Deliarnoor, the purpose of referring Acting Officers in several regions is to replace the definitive regional head so that the government could remain working. ${ }^{10}$ However, the Acting Officers' authority is limited since they are not allowed to take strategic actions or policies as in Article 132A Government Regulation 49/2008 of the Third Amendment to Government Regulation 6/2005 on the Regional Head Election, Ratification of Appointments, and Dismissal of Regional Heads and Deputy Regional Heads (Government Regulation Acting Officers). ${ }^{11}$ The Acting Officers are not permitted to create the strategic policies. Thus, it is feared that this could hinder the mayor's democracy in a region. Another opinion by Richard Kennedy and Bonaventura Pradana Suhendarto infer strategies to prevent the void position. Some alternatives to fill regional head positions might be the solution, such as assigning the Acting officers. ${ }^{12}$ Nonetheless, Kennedy also stated if the Acting Officers' assignation was not very efficient, considering they only had limited authority. It could not be optimal and efficient yet because the Acting Officers are not permitted to create the strategic policies.

A new issue that emerged for several groups' debates is the draft revision of the Election Act of May 6, 2020. It stated that the 2021 Indonesian House of Representatives' priority regulating plans for Regional Head Election was to be conducted in 2022 and $2023 .{ }^{13}$ The revised draft of the Election Law version of May 6, 2020, shows that Regional Head Election, which was previously held in 2020, resulted in many conflicts. However, it did not

10 Nandang Alamsah Deliarnoor, "Problematika Pelaksana Tugas (Plt) Dalam Masa Transisi Pemerintahan (Pra Dan Pasca Pilkada Serentak)" (2017) 1:2 CosmoGov 322.

11 Ibid at 322.

12 Richard Kennedy \& Bonaventura Pradana Suhendarto, "Diskursus Hukum: Alternatif Pola Pengisian Jabatan Kepala Daerah di Masa Pandemi Covid-19" (2020) 2:2 J Pembang Huk Indones 188-204 at 2.

13 Newsantara, "Tahapan Pemilu 2022, Pilpres dan Pileg 28 Februari 2024 Newsantara.id", online: <https://newsantara.id/2021/06/04/tahapan-pemilu-2022pilpres-dan-pileg-28-februari-2024/>. 
become a serious consideration taken by the government, the House of Representatives, and the General Election Commission, while the COVID-19 transmissions in Indonesia were still high. Therefore, a new study or research is needed to thoroughly discuss the polemics caused by Regional Head Election during the pandemic.

The main problem is to what extent the discourse on the Regional Head Election during the COVID-19 pandemic? To facilitate analysis and discussion, it has two main discussions. The first discussion provides an indepth overview of the crucial stages of regional head elections, including voter data verification and campaign issues during the COVID-19 pandemic. The second discussion examines the implementation of the Regional Head Election during the pandemic.

\section{METHODS}

The research method combined doctrinal ${ }^{14}$ and empirical legal research methods. This method makes the legal research paradigm use other scientific approaches so that the legal issues discussed could be solved by remaining based on the norms and laws and regulations. ${ }^{15}$ The primary data sources were the laws and regulations relating to the Regional Head Elections in Indonesia and the results of interviews from the Election Supervisory Committee of Kenjeran District of Surabaya and the Election Organizing Group Committee of Tambak Sari District, Surabaya. The secondary data sources used theories, principles, dogmas, legal doctrines, and research from books, journal articles, news, research papers, and other relevant sources.

${ }^{14}$ A'an Efendi, Dyah Ochtorina Susanti \& Rahmadi Indra Tektona, Penelitian Hukum Doktrinal (LaksBang Justitia, 2019).

15 Ahmad Zuhdi Muhdlor, "Perkembangan Metodologi Penelitian Hukum" (2012) 1:2 J Huk Dan Peradil 189-206. 


\section{CRUCIAL STAGES OF REGIONAL HEAD ELECTIONS}

\section{A. Stages of Voter Data Matching and Voter Data Updating}

Article 34(1) of Law 10/2008 on Elections outlines that the City/County's General Election Commission updates voter data based on population data from the Government and local governments. ${ }^{16}$ In general, the process and research of Voter Data Matching to the voters is carried out door to door by the Voters List Update Committee. ${ }^{17}$ Due to the knowledge and access of Sub-District Election Committee and Voting Committee require the communication proximity with residents' representatives, such as the urban village head, neighborhood/hamlet head, or another personage in the urban village area. ${ }^{18}$ This approach is vital for mapping the distribution of voters in the voting place to match and examine the suitability of the Permanent Voter Data in each voting place in the assigned urban village area. ${ }^{19}$

According to Himawan Estu Bagijo, if the population data submitted by the Government and Local Government to election organizers is accurate enough and political party officials at the urban village area and community levels play an active role in the Voter Data Matching process, so they could get accurate the Permanent Voter Data results. ${ }^{20}$ Therefore, the Stages of Voter Data Matching and Voter Data Updating must be carried out directly or door-to-door to get accurate results. However, in the current situation of the pandemic, the Voter Data Matching process is impossible to do directly, considering that this will cause a crowd that would increase faster the COVID-19 transmission. To avoid crowds, the Voters List

16 Indonesia, Law 10/2008 concerning General Election of Members of the People's Representative Council, Regional Representative Council, and Regional People's Representative Council.

17 KPU Yogyakarta, "Coklit (Pencocokan Dan Penelitian): Apa dan Bagaimana? KPU DIY”, online: <https://diy.kpu.go.id/web/coklit-pencocokan-dan-penelitianapa-dan -bagaimana/>.

18 Ibid.

19 KPU Kota Palu, "Coklit Salah Satu Cara Memutakhirkan Data Pemilih | KPU Kota Palu”, online: <https://kota-palu.kpu.go.id/coklit-salah-satu-cara-memutakhirkandata-pemilih/>.

20 Himawan Estu Bagijo, "Daftar Pemilih Tetap Dan Perlindungan Hak Pilih (Kajian Perundang-Undangan Dan Keputusan Mahkamah Konstitusi)" (2010) 15:4 Perspektif 335 at 4. 
Update Committee should try online Voter Data Matching (maximizing the use of information and technology).

The online Voter Data Matching might not be done effectively, where Voter Data Matching was always be done by going to people's homes previously. However, this online Voter Data Matching aims to reduce the virus transmission rate, especially the COVID-19 is mutating into the new vary. It is not easy to do online Voter Data Matching due to the lack of experience in previous years. Thus, it will take a long preparation time. However, some parties argue that implementing online Voter Data Matching by the Voters List Update Committee would also result in difficulty for voters with technology illiterate or who have no smartphone. To overcome this, General Election Commission and other committees should do socialization through leaflets and television media to socialize how to implement online Voter Data Matching to avoid crowds. The Voter Data Matching officers are prohibited from contacting voters. Even if some voters do not have a smartphone, the Voters List Update Committee still goes to the voters' house using Personal Protective Equipment (PPE). It minimizes the occurrence of direct interaction. However, there is one important thing when the Voter Data Matching process must be conducted online. It is only temporary to maintain the continuity of the simultaneous elections during the pandemic. The next stage of the Regional Head Election is planned in 2022 in the condition of the pandemic, which could not be predicted when it will end. Thus, maximizing the use of information and technology is essential to replace the conventional election stages, which require the strict COVID-19 health protocol.

\section{B. Requirements Verification for the Regional Head Candidate}

Based on General Election Commission Regulation 6/2020 of the third amendment to General Election Commission Regulation 13/2019 about the Stages, Programs, and Schedules for implementing the 2020 Regional Head Election. Several stages of Regional Head Election must be carried out, one of which is verifying the Regional Head Candidate done by the 
City/County General Election Commission. One of the purposes of the Regional Candidate verification is to avoid manipulative practices. Articles 40 and 41 of the Regional Head Election Law stated that there are two mechanisms for nominating Regional Head Election, through a political party or coalition of political parties and independent.

In the process of verifying the independent candidate, a different mechanism is needed from the political party. The stages of verification of the independent Regional Candidate are under some steps. First, check the terms of the amount of support and distribution..$^{21}$ Second, administrative verification. ${ }^{22}$ Third, factual verification. ${ }^{23}$ Fourth, submission of repair support requirements. ${ }^{24}$ Fifth, verification of correcting administration. ${ }^{25}$ Sixth, factual verification of repairs. ${ }^{26}$ Of all the verification stages, it is necessary to have a direct meeting between the City/County General Election Commission and the parties for the Regional Head Candidate. The candidate's data checking is essential to avoid invalid data, especially during the pandemic. Prone to falsification of data for an independent candidate.

One of the crucial processes in implementing independent candidate verification is the factual verification of support requirements for individual candidates. ${ }^{27}$ In the factual verification mechanism process, the City/County General Election Commission will use methods such as the population census. ${ }^{28}$ Based on Article 48 of the Regional Head Election Law, there are two types of verification. Those are administrative

21 Ahkam Jayadi, "Mekanisme Verifikasi Calon Kepala Daerah Jalur Perseorangan" (2020) 2:5.

22 Ibid.

23 Ibid.

${ }^{24}$ Ibid.

25 Ibid.

${ }^{26}$ Ibid.

27 Supriyadi Supriyadi, "Menakar Nilai Keadilan Penyelenggaraan Pilkada 2020 di Tengah Pandemi Covid-19” (2020) 22:3 Kanun J Ilmu Huk 493-514 at 22.

28 Robiatun Adawiyah, Kajian kritis persyaratan pencalonan kepala daerah jalur perseorangan dibubungkan dengan pasal 18 ayat (4) Undang-Undang Dasar 1945 sebagai upaya rekonstruksi pilkada demokratis (masters, UIN Sunan Gunung Djati Bandung, 2017). 
verification and factual verification for three days using the census method. The factual verification process is carried out directly to each candidate's supporters who submit their ID cards. While the supporters of the Regional Head Candidates could not be found, they are allowed to present them at the Voting Committee office. ${ }^{29}$

The stage of the factual verification process for an independent candidate in the previous Regional Head Election has generated many conflicts for some. It is considered too burdensome, especially during the pandemic. Another problem arises when it requires Voting Committee officers to gather candidate's supporters in a forum, as stated in Article 38(1) of General Election Commission Regulation 6/2020. The census method carried out in factual verification would endanger the Voting Committee officers and supporters due to the spread of the COVID-19.30 This mechanism could be against Government Regulation 21/2020 about the Large-Scale Social Restrictions because it causes public crowds.

It is difficult to change the factual verification process using other alternatives in the current pandemic, especially online. However, urgency, such as the current pandemic, could be overcome through a health examination process. The candidate's determination is not carried out simultaneously, as explained in Article 50C(1) and (5) of General Election Commission Regulation 10/2020. ${ }^{31}$ Other alternatives that could be used at this stage are: voting officers verify the factual support of the Prospective Individual Candidate Pair by implementing strict physical distancing protocols; the recapitulation support is carried out in stages starting from the voting officers to the provincial level using online media (maximizing the use of information and technology). The factual verification of revision support by voting officers is no longer door-to-door but by gathers supporters somewhere by doing the strict COVID-19 protocol and limiting the number of supporter attendees or being carried out in stages to prevent transmission of the COVID-19.

\footnotetext{
${ }^{29}$ Ibid.

30 Supriyadi, supra note 27.

31 Adawiyah, supra note 28.
} 


\section{Stages of Campaign}

Political campaigns are one of the crucial agendas in pre-election. The campaign is a forum, and a means for candidates to conduct political communication with prospective voters. It makes this campaign activity mandatory at every political party. According to Rogers and Story campaign is a series of planned communication actions to create a particular effect on the general public, which is carried out continuously over a certain period..$^{32}$

In its implementation, campaign activities are based on the persuasion principle by inviting and encouraging people to do or not do something voluntarily. ${ }^{33} \mathrm{McQuail}$ and Windahl stated that the campaign's target is the large part of the community who have knowledge, attitudes, and behaviors that could later be changed through these activities. ${ }^{34}$ The campaign's purpose is to gain support from the public with a large target audience.

Campaign activities in the current pandemic situation are not accessible. Many aspects need to be considered so the campaign cannot create a new cluster in the transmission of the COVID-19. It has been regulated, following General Election Commission Regulation 5/2020 on the Third Amendment to the Election Commission Regulation 15/2019 concerning the Stages, Programs, and Schedules of The Election of Governors and Deputy Governors, Regents, and Deputy Regents, and Mayors and Deputy Mayors in 2020. Under Article 57 of General Election Commission Regulation 6/2020, there are several changes in implementing the campaign. These include limited meetings, face-to-face meetings and dialogues, public debates or open debates between pairs of candidates, dissemination of campaign materials to the public, and installation of campaign props. ${ }^{35}$

32 Fauzan Ali Rasyid, "Kampanye Politik dan Persoalan Bangsa" (2009) 25:2 Mimbar 10.

33 Ibid.

34 Denis McQuail, Audience Analysis, 1st ed (SAGE Publications Ltd, 1997).

35 Supriyadi, supra note 27. 
Several legal issues have sparked polemics among Indonesian people regarding campaign activities during the pandemic. The following is a cons list of several Regional Head Election campaign activities in 2020 during a global pandemic (electronic media version). First; Election campaign activities carried out by the candidates for Mayor and Deputy Mayor of Bukit Tinggi, West Sumatra, Ramlan, and Syahrizal. This activity is clearly against Government Regulation 21/2020 about the Large-Scale Social Restriction. Second; A campaign held by supporters of the candidate pairs for the Regent and Deputy Regent of Ponorogo, East Java, Ipong Muchlissoni, and Bambang Tri Wahono overrides health protocols. Even sympathizers from the two candidates held an art performance in front of the Ponorogo Regional General Election Commission office, attended by hundreds of supporters. Then, several other legal issues regarding the election campaign amid the pandemic reaped cons from the public.

The polemic that is commonly discussed is about being allowed to hold music concerts during the pandemic. Whereas in Government Regulation $21 / 2020$, it is clearly stated that all types of activities that cause crowds are not allowed. Regarding the polemic, the General Election Commission has confirmed that the procurement of music concerts during the Regional Head Election during this pandemic must pass several requirements. Among them, the number of campaign participants could not be more than 50 people. All participants are required to apply health protocols to break the chain of spreading COVID-19. However, the law and the appeal from the General Election Commission do not work as expected.

The polemic on the legal issues above illustrates that there are still many people who ignore health protocols. It needs to be considered and reviewed by the government, the General Election Commission, and the Election Supervisory Board in preparing for the next election stage. The transmission number of the COVID-19 virus in Indonesia is still very high. Consideration and review could be accomplished by providing a clear emphasis on the existing laws and regulations. The Regional Head Election campaign may repeat in the election campaign in the coming year. 
In the next election, the Indonesian government should learn from the success of South Korea in holding elections during the COVID-19 outbreak. As in South Korea, the people vote through two methods; early voting and voting at the polling station. ${ }^{36}$ South Korea also implemented strict health protocols so that the transmission rate of the COVID-19 did not highly increase during the election. South Korea replaces political campaigns differently. Instead of gathering in massive rallies, the candidates campaign by cleaning public places in their neighborhood. ${ }^{37}$ This could be used as an example for other countries, especially Indonesia, to preserve democracy and public health in the future.

Article 63(1) of the General Election Commission Regulation 10/2020 has explained several provisions which are considered not violating the campaign provisions. Hence, the General Elections Commission must amend the campaign provisions in General Election Commission Regulation 5/2020 adjusted to the current pandemic conditions. One of which is implementing campaign activities done by South Korea and the Election Commission Regulations should impose strict sanctions, like the disqualification of violators as a deterrent effect.

\section{Stages of Voting and Vote Counting}

Voting and counting refer to Law 9/1999 on Human Rights, in which the constitution guarantees the right to vote for every citizen. Voting is giving votes from voters to the candidate pairs or political parties of their choice. Vote counting is the process of counting the voting results. Both activities are carried out within one day; voting is in the morning, and vote-counting is in the afternoon up to evening. Voting and counting votes are divided into three main activities: preparation, voting, counting of votes, and

${ }^{36}$ Kompas.com, "Penjelasan Dubes RI soal Keberhasilan Pemilu Korsel di Tengah Pandemi”, online: <https://nasional.kompas.com/read/2020/10/21/09510551/ penjelasan-dubes-ri-soal-keberhasilan-pemilu-korsel-di-tengah-pandemi> .

37 VOA Indonesia. "Korea Selatan Langsungkan Pemilu di tengah Pandemi Corona”, online: <https://www.voaindonesia.com/a/korea-selatan-langsungkan-pemilu-ditengah-pandemi-corona-/5373580.html>. 
administration (filling in the minutes and other complete documents). ${ }^{38} \mathrm{In}$ the preparatory stage, the activities started from receiving election logistics, distributing voter notification letters (Model C6) to voters, and establishing a voting station.

Furthermore, the voting and counting process is carried out in stages and time determined by the Voting Organizing Group. The third stage is administration. The administrative and vote counting process includes the official document (Model C, Model C1 Plano, Model C1 and its attachments, Model C2, Model C3, Model C4, and Model C5), attendance list, the announcement of the Permanent Voter Data, Additional Voters List, List of Voters Special Voters and other documents that the Voting Organizing Group must fill out. All of the activities mentioned above require public space for their implementation, which means that these activities require election organizers and voters to interact directly.

There is another alternative to carry out the voting stages and counting votes during this outbreak by e-voting or electronic voting. Electronic voting is a method of voting and counting votes using electronic devices. ${ }^{39}$ The Council of Europe $(\mathrm{CoE})$ defines e-voting as an electronic voting device that can speed up data tabulation, reduce election costs, and contribute to preventing unauthorized voters. ${ }^{40} \mathrm{E}$-voting must have at least three mandatory parameters; Convenience, Flexibility, and Mobility. ${ }^{41}$ Evoting does not require a smartphone since, in the election process, voters could use the Short Message Service (SMS) application. It provides convenience for residents who do not have a smartphone or are constrained

38 Masmulyadi, et al., Serial Evaluasi Penyelenggaraan Pemilu Serentak 2019 Peribal Pemungutan dan Penghitungan Suara, 1st ed (Badan Pengawas Pemilihan Umum, 2019).

39 Slamet Risnanto, “Aplikasi Pemungutan Suara Elektronik/E-Voting Menggunakan Teknologi Short Message Service Dan at Command" (2017) 10:1 J Tek Inform at 10.

40 Irham Mulkan Rodiana, Budi Rahardjo \& W Aciek Ida, "Design of a Public Key Infrastructure-based Single Ballot E-Voting System” (2018) 2018 Int Conf Inf Technol Syst Innov ICITSI 2018 - Proc 6-9 at 6-9.

41 Risnanto, supra note 39 at 10. 
by the internet network in their area. In addition to SMS, the Voting Organizing Group provides an application on a smartphone for voters to directly submit their vote. The e-voting process is not an obstacle in implementing the Regional Head Election amid the pandemic. Along with the development of technology, many technical guidance activities are held by government agencies to upgrade the skills in the electronics field for employees, especially in the government sector. The Voting Organizing Group officers could socialize through representatives of village officials, in this case, Head of Neighborhood or Head of Hamlet. They also can use leaflets, and even social media, considering that many people are more enthusiastic about everything is presented by several social media. The City/County General Election Commission could support the socialization of the e-voting system through television broadcasts. Consequently, the dissemination of information could be received by the public quickly.

Suppose there are still difficulties in implementing electronic voting and vote counting. In that case, the General Election Commission may seek the following: First, limit the number of voters who enter the polling station (this has been done by several polling stations in the 2020 regional elections simultaneously). Second, propose a mechanism for making a mobile voting station. This aims to avoid cluster elections due to crowds. Third, make guidelines for voters at polling stations according to physical distancing rules. Fourth, make guidelines of the voting station officers according to physical distancing rules. Fifth, design the voting station standards by the COVID-19 protocol. These efforts must be accompanied by clear and firm sanctions to prevent violations in the 2020 campaign activities.

\section{IMPLEMENTING SIMULTANEOUS ELECTIONS DURING THE COVID-19 PANDEMIC}

The postponement of the Regional Head Election would result in a position void for regional heads in some regions. There needs to be a solution to fill the vacant position, so the ongoing wheels of government and development in the area keep running. One possible alternative is to use an indirect election system. Indirect elections are not a new election 
pattern. This system has been used in the historical development of the Regional Head Election in Indonesia. Indirect elections have been held since June 1, 2005. However, at that time, not all regions used this system due to the region's peculiarities. For example, at that time, the Special Region of Yogyakarta (now known as DIY) and DKI Jakarta. ${ }^{42}$ The governor determines the election process for the Mayor and Deputy Mayor in the two regions. Article 18(4) of the 1945 Constitution regarding Regional Head Election could be interpreted as direct elections by the people or indirect elections through Regional People's Representative Council representation. ${ }^{43}$ Previously, indirect elections were regulated in Law 22/1999. However, the implementation of indirect elections was considered an injury to democracy because the people could not make their own choices. Thus, the indirect regional election law was changed to direct regional election following Law $1 / 2015$ before finally being changed to the 2020 regional election law; the urgency of the pandemic.

Indirect elections could be used as an alternative to avoid a vacancy in the position of regional heads as long as the pandemic has not ended. Besides that, indirect elections could also save state expenditures for the implementation of regional elections. The regional elections are not directly carried out through representatives of each region's Regional People's Representative Council. In addition, the latest Regional People's Representative Council elections were held in 2019 before the pandemic occurred. The indirect Regional Head Election system is considered a reasonably effective way to do it. It does not create crowds during its implementation. Many people may think that the indirect Regional Head Election would cause many conflicts, especially regarding corruption. The public considers that the indirect election is prone to fraud because it is carried out without the people's knowledge, especially since the law has guaranteed the right to vote.

42 Jawapos, "Pilkada Langsung dan Tidak Langsung", online: <https://www.jawapos. com/opini/15/11/2019/pilkada-langsung-dan-tidak-langsung/>.

43 Muhammad Bahrul Ulum, "How Democracy Is Election? Reassessing Article 18 (4) of The 1945 Constitution and Its Implication to the Regional Head Election in Indonesia” (2019) 8:2 J Huk Dan Peradil 315. 
Discourse on indirect elections was conveyed by the Minister of Home Affairs Tjahjo Kumolo with the chairman of the 2019 Indonesian House of Representatives, Bambang Soesatyo. They stated that indirect elections have advantages such as low political costs. In addition, money politics does not extend to the community base, and the people do not experience extreme divisions socially or politically. ${ }^{44}$ However, reverted to the people's poll, Regional Head Election is not considered an unfair form of democracy.

Another alternative to replacing simultaneous regional elections during the pandemic is the appointment of Acting Officers. Previous research stated that Acting Officers' appointment as a replacement for the Regional Head was considered ineffective because the Acting Officers had only limited authority. Also, they could not take strategic policies, stated in Article 132A of Government Regulation 49/2008. However, there are some alternatives. First, amend the Local Government Law, which regulates the authority of the Acting Officers. Second, people could suggest their laws in purpose. The law in question could be explicitly made or incorporated into other law-level regulations whose discussion topics do not deviate from the regulations of the Acting Officers.

Based on the analysis results above, the alternative of filling the vacant position of regional heads through the Regional Head Election and the indirect Regional Head Election has its respective advantages and disadvantages. Choosing Acting Officers as a substitute for regional heads who are in transition is more effective. The appointment of the Acting Officers does not harm Indonesia's political democracy as the implementation of indirect elections. Indonesia is a democratic country. Thus indirect elections are no longer effective if it is re-implemented.

${ }^{44}$ Okezone, "Wacana Pilkada Tidak Langsung, Ini Kelebihan dan Kekurangannya", online: <https://nasional.okezone.com/read/2018/04/10/337/1884413/wacanapilkada-tidak-langsung-ini-kelebihan-dan-kekurangannya $>$ 


\section{CONCLUSION}

The simultaneous elections during the COVID-19 pandemic were held in Indonesia as part of the democratic cycles despite avoiding the vacancies at the regional levels. Its implementation was adjusted to the pandemic situation, and several aspects considered the election in this pandemic. First, the government strived to implement the health protocols as standardized by the WHO strictly. Second, it prepared more detailed and comprehensive-time simulations to adjust the overall implementation of the election stages. Third, the government ensured the internet infrastructure throughout the region by facilitating offline and online meetings. Fourth, it created new guidelines for all stages of the Regional Head Election based on the COVID-19 health protocol. While the election is postponed until the pandemic ends, the government may take an alternative by applying Acting Officers in lieu of the current regional heads. In doing so, the Acting Officers could run the government with full authority by firstly required to amending the existing Regional Government Law.

\section{ACKNOWLEDGMENTS}

None.

\section{REFERENCES}

Adawiyah, Robiatun, Kajian kritis persyaratan pencalonan kepala daerah jalur perseorangan dihubungkan dengan pasal 18 ayat (4) UndangUndang Dasar 1945 sebagai upaya rekonstruksi pilkada demokratis (masters, UIN Sunan Gunung Djati Bandung, 2017).

Bagijo, Himawan Estu, "Daftar Pemilih Tetap dan Perlindungan Hak Pilih (Kajian Perundang-Undangan dan Keputusan Mahkamah Konstitusi)" (2010) 15:4 Perspektif 335.

Cucinotta, Domenico \& Maurizio Vanelli, "WHO Declares COVID-19 a Pandemic” (2020) 91:1 Acta Bio-Medica Atenei Parm 157-160. 
Deliarnoor, Nandang Alamsah, "Problematika Pelaksana Tugas (Plt) dalam Masa Transisi Pemerintahan (Pra dan Pasca Pilkada Serentak)" (2017) 1:2 CosmoGov 322.

Efendi, A'an, Dyah Ochtorina Susanti \& Rahmadi Indra Tektona, Penelitian Hukum Doktrinal, 1st ed (LaksBang Justitia, 2019).

Geovanie, David Greacy, "Urgensi Penyelenggaraan Pilkada Pada Masa Pandemi Covid-19 Di Indonesia” (2020) 1 J Locus Delicti 7.

Herdiana, Dian, "Implementasi Kebijakan Pembatasan Sosial Berskala Besar (PSBB) Sebagai Upaya Penanggulangan Corona Virus Disease 2019 (COVID-19)" (2020) 2:2 Decis J Adm Publik 14.

Hergianasari, Putri, "Electoral Distancing: Alternatif Penyelenggaraan Pemilihan Kepala Daerah 2020 Ditengah Covid-19 Di Indonesia" (2020) 1:1 Magistrorum Sch J Pengabdi Masy 112-121.

Jawapos, "Pilkada Langsung dan Tidak Langsung", online: <https://www. jawapos.com/opini/15/11/2019/pilkada-langsung-dan-tidaklangsung/>.

Jayadi, Ahkam, "Mekanisme Verifikasi Calon Kepala Daerah Jalur Perseorangan" (2020) 25.

Kennedy, Richard \& Bonaventura Pradana Suhendarto, "Diskursus Hukum: Alternatif Pola Pengisian Jabatan Kepala Daerah di Masa Pandemi Covid-19" (2020) 2:2 J Pembang Huk Indones 188-204.

Kompas.com, "Penjelasan Dubes RI soal Keberhasilan Pemilu Korsel di Tengah Pandemi”, online: <https://nasional.kompas.com/read/2020/ 10/21/09510551/penjelasan-dubes-ri-soal-keberhasilan-pemilukorsel-di-tengah-pandemi>.

KPU Kota Palu, "Coklit Salah Satu Cara Memutakhirkan Data Pemilih | KPU Kota Palu”, online: <https://kota-palu.kpu.go.id/coklit-salahsatu-cara-memutakhirkan-data-pemilih/>.

KPU Yogyakarta, "Coklit (Pencocokan dan Penelitian): Apa dan Bagaimana? - KPU DIY", online: <https://diy.kpu.go.id/web/coklitpencocokan-dan-penelitian-apa-dan-bagaimana/>. 
Masmulyadi, et al., Serial Evaluasi Penyelenggaraan Pemilu Serentak 2019 Perihal Pemungutan dan Penghitungan Suara, 1st ed (Badan Pengawas Pemilihan Umum, 2019).

McQuail, Denis, Audience Analysis, 1st ed (SAGE Publications Ltd, 1997).

Muhdlor, Ahmad Zuhdi, "Perkembangan Metodologi Penelitian Hukum" (2012) 1:2 J Huk Dan Peradil 189-206.

Nargis, Nila \& M Iwan Satriawan, "Legal Problems on Regional Head Election during COVID-19 Pandemic in Indonesia" (2021) 2:1 Constitutionale 69-78.

Navarrro-Vargas, José Ricardo, “The COVID-19 pandemic" (2020) 68:1 Rev Fac Med 7-8.

Newsantara, "Tahapan Pemilu 2022, Pilpres dan Pileg 28 Februari 2024, online: <https://newsantara.id/2021/06/04/tahapan-pemilu-2022pilpres-dan-pileg-28-februari-2024/>.

Okezone, "Wacana Pilkada Tidak Langsung, Ini Kelebihan dan Kekurangannya: Okezone Nasional”, online: <https://nasional. okezone.com/read/2018/04/10/337/1884413/wacana-pilkada-tidaklangsung-ini-kelebihan-dan-kekurangannya>.

Rasyid, Fauzan Ali, "Kampanye Politik dan Persoalan Bangsa" (2009) 25:2 Mimbar 10.

Risnanto, Slamet, "Aplikasi Pemungutan Suara Elektronik/E-Voting Menggunakan Teknologi Short Message Service Dan At Command" (2017) 10:1 J Tek Inform.

Ristyawati, Aprista, "Efektivitas Pelaksanaan Pilkada Serentak 2020 Pada Masa Pandemi Darurat COVID-19 di Indonesia" (2020) 2:2 Crepido 85-96.

Rodiana, Irham Mulkan, Budi Rahardjo \& W Aciek Ida, "Design of a Public Key Infrastructure-based Single Ballot E-Voting System" (2018) 2018 Int Conf Inf Technol Syst Innov ICITSI 2018 - Proc 69. 
Supriyadi, Supriyadi, "Menakar Nilai Keadilan Penyelenggaraan Pilkada 2020 di Tengah Pandemi Covid-19" (2020) 22:3 Kanun J Ilmu Huk 493-514.

Ulum, Muhammad Bahrul, "How Democracy Is Election? Reassessing Article 18 (4) of the 1945 Constitution and Its Implication to the Regional Head Election in Indonesia” (2019) 8:2 J Huk Dan Peradil 315.

VOA Indonesia, "Korea Selatan Langsungkan Pemilu di tengah Pandemi Corona", online: <https:/www.voaindonesia.com/a/korea-selatanlangsungkan-pemilu-di-tengah-pandemi-corona-/5373580.html>.

WHO, "WHO Coronavirus (COVID-19) Dashboard | WHO Coronavirus (COVID-19) Dashboard With Vaccination Data", online: <https://covid19.who.int/>.

Zhong, Bao-Liang, et al., "Knowledge, attitudes, and practices towards COVID-19 among Chinese residents during the rapid rise period of the COVID-19 outbreak: a quick online cross-sectional survey" (2020) 16:10 Int J Biol Sci 1745-1752. 